\title{
An Overview of Mycotoxicosis and Human's Health Concerns: A Mini-Review
}

\section{ISSN: 2640-9208}

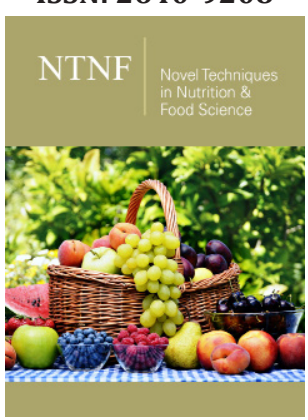

${ }^{* 1}$ Corresponding author: Channaiah LH, AIB International Inc., USA

Submission: 㘹 May 16, 2019

Published: 眥 May 29, 2019

Volume 4 - Issue 1

How to cite this article: Lakshmikantha $\mathrm{H}$ Channaiah $^{1,2, *}$. An Overview of Mycotoxicosis and Human's Health Concerns: A Mini-Review. Nov Tech Nutri Food Sci. 4(1).NTNF.000576.2019. DOI: 10.31031/NTNF.2019.04.000576

Copyright@ Lakshmikantha H Channaiah $^{1,2, *}$, This article is distributed under the terms of the Creative Commons Attribution 4.0 International License, which permits unrestricted use and redistribution provided that the original author and source are credited.

\author{
Lakshmikantha H Channaiah ${ }^{1,2, *}$ \\ ${ }^{1}$ AIB International Inc., 1213 Bakers way, Manhattan, KS 66502, USA \\ ${ }^{2}$ School of Food Science, Washington State University, Pullman, WA 99164, USA
}

\begin{abstract}
Mycotoxicosis are acute diseases caused by mycotoxins, which are secondary metabolites produced by certain filamentous fungi (e.g., Aspergillus flavus, A. parasiticus, Fusarium spp. etc.) belonging to the phylum Ascomycota [1-3]. Depending on the type of toxin, and its quantity, as well as the age, sex, length of exposure and the immune status of the exposed person, mycotoxicosis can be carcinogenic, mutagenic, neurotoxic, hemorrhagic etc. [4-6]. Furthermore, the severity of the mycotoxicosis can be compounded by factors such as malnutrition, other infectious diseases, and alcohol abuse [7].
\end{abstract}

Keywords: Mycotoxins; Health risk

\section{Introduction}

Consumption of mycotoxin contaminated food is the major source of human exposure to mycotoxins, and there are almost no treatments for mycotoxicosis [7]. Cereals grains (e.g., corn, wheat, sorghum), oilseeds (e.g., peanut, sunflower etc.), spices (black pepper, turmeric etc.), fruits (peach, grapes etc.), beans (e.g., coffee), nuts (e.g., walnut, pistachio, almond etc.) can be contaminated with various mycotoxins [8]. Additionally, milk (human, cow, sheep etc.), cheese, butter can also be a source of mycotoxin-contamination due to consumption of mycotoxin contaminated animal food products [9]. The clinically important mycotoxins that cause severe health implications in humans are aflatoxin, fumonisin, vomitoxin (deoxynivalenol), ochratoxin A, patulin, T-2 Toxin, and zearalenone (Table 1). The human health effects or disorders due to consumption of mycotoxin contaminated foods includes diarrhea, reproductive disorder, cancer, growth impairment and immunomodulation [4].

Worldwide, nearly $25 \%$ of the world's crop every year is contaminated with mycotoxins causing huge economic, nutritional and health crisis in humans as well as in the livestock industry [3]. There are $\sim 400$ defined mycotoxins $[7,8]$. Almost all mycotoxins can cause one or more health problems in humans and animals, in addition to suppressing the immune system in humans [6]. Mycotoxins are colorless, odorless, and hence cannot be detected by visual inspection such as smell or taste. In addition to ingestion, occupational exposure to mycotoxins has also been the subject of several health hazard studies [10,11]. Air samples collected in grain elevator and feed manufacturing environment showed high levels of aflatoxins and vomitoxins indicating occupational exposure risk to workers [4]. Fundamental studies on the synthesis of mycotoxins in filed, grain storage and its effect in animal models is well documented in scientific literature [7,12,13]. Nearly 16,821 papers on mycotoxins were recorded from mid-1960s to 2018 in Scopus [5]. However, due to inconsistency in mycotoxins susceptibility in test animals, and other pre-existing medical conditions it has been difficult to extrapolate the clinical side effects of mycotoxins to humans. Studies on effect of mycotoxins on nutrient absorption is limited. The impairment of child growth due to mycotoxins exposure remains to be elucidated. Furthermore, the clinical side effects of ochratoxin A and zearalenone and trichothecenes exposure need to be defined scientifically. Inability to accurately quantify the mycotoxin exposure at the individual level is another limitation. Recently, the use of biomarkers has greatly assisted the epidemiological studies in relation to various human health disorders such as cancer, child growth impairment, and immune effects $[14,15]$. 
Table 1: Major mycotoxins, predominant fungal source, target food, and associated health effects in human.

\begin{tabular}{|c|c|c|c|c|}
\hline Mycotoxin & $\begin{array}{l}\text { Predominant Fungal } \\
\text { Source }\end{array}$ & Target Food Items & Associated Health Effects in Human & $\begin{array}{c}\text { Classification as per } \\
\text { the IARC* }\end{array}$ \\
\hline Aflatoxins (B1, B2, G1, G2) & $\begin{array}{l}\text { Aspergillus. flavus, } \\
\text { A. parasiticus }\end{array}$ & $\begin{array}{l}\text { Corn, peanut, oilseeds, } \\
\text { tree nuts }\end{array}$ & $\begin{array}{l}\text { Carcinogenic, hepatotoxic and immuno- } \\
\text { suppressive }\end{array}$ & Group 1B \\
\hline Vomitoxin/ deoxynivalenol & $\begin{array}{l}\text { Fusarium graminearum, } \\
\text { F. culmorum }\end{array}$ & Wheat, corn, barley & $\begin{array}{l}\text { Vomiting, nausea, diarrhea, toxicosis, and } \\
\text { reproductive disorder }\end{array}$ & Group 3 \\
\hline Fumonisins & $\begin{array}{l}\text { F. verticillioides, } \\
\text { F. moniliforme, } \\
\text { F. proliferatum }\end{array}$ & Corn, rice, sorghum & $\begin{array}{l}\text { Nephrotoxic, carcinogenic, immunosup- } \\
\text { pressive }\end{array}$ & Group 2B \\
\hline Ochratoxin A & $\begin{array}{c}\text { A. carbonarius, } \\
\text { A. niger, } \\
\text { Penicillium verrucosum }\end{array}$ & $\begin{array}{l}\text { Wheat, corn, barley, } \\
\text { coffee, oats }\end{array}$ & $\begin{array}{l}\text { Genotoxic, carcinogenic, immunosup- } \\
\text { pressive }\end{array}$ & Group 2B \\
\hline Zearalenone & $\begin{array}{l}\text { F. graminearum, } \\
\text { F. culmorum }\end{array}$ & Corn, sorghum, wheat & Carcinogenic, reproductive disorder & Group 3 \\
\hline Patulin & $\begin{array}{l}\text { P. expansum, } \\
\text { Byssochlamys }\end{array}$ & $\begin{array}{l}\text { Cereals, apple, olives, } \\
\text { grapes, peach }\end{array}$ & Neurologic and gastrointestinal disorders & Group 3 \\
\hline
\end{tabular}

IARC: International Association on Research for Cancer.

Group 1: Carcinogenic to humans, Group 2A: Probably carcinogenic to humans, Group 2B: Possibly carcinogenic to humans, and Group 3: Not classifiable as to its carcinogenicity to humans (IARC 2012).

Source: Channaiah [2], Channaiah \& Maier [8]; Durate et al. [17]; Ostry et al. [19]; IARC [18]; Omotayo et al. [6].

\section{Conclusion}

By 2050 the world's population is expected to reach 9.1 billion, with an estimated 2.3 billion increase in the developing countries [16]. The impact of mycotoxins on human health can be severe in the developing countries because of a combination of social, agriculture, economic and political scenarios. The mycotoxin contaminated foods have the potential to alter the nutrient absorption, gut microbiota, and immune stimulatory compounds such as lipopolysaccharides (LPS). Additionally, the side effect of mycotoxins on LPS has been linked to hypercholesterolemia, which is one of the major human health concerns of the $21^{\text {st }}$ century [17-19]. The measurement of plasma LPS and the related clinical disorders due to mycotoxin contaminated food may further assist the severity of mycotoxicosis in the developing world. The future epidemiological research should focus on the quantitative measurement of mycotoxin contaminated food, its impact on LPS and related clinical disorders in patients in order to establish adequate public health measures.

\section{References}

1. Peraica M, Radic B, Lucic A, Pavlovic M (1999) Toxic effects of mycotoxins in humans. Bulletin of the World Health Organization 77(9): 754-766.

2. https://www.qualityassurancemag.com/article/aib0814-toxic-fungicontamination-concerns/

3. Alshannaq A, Hyuk YJ (2017) Occurrence, toxicity and analysis of major mycotoxins in food. Int J Environ Res Public Health 14(6): 632.

4. IARC (2012) Mycotoxins and human health (Chapter-6), In: Pitt JI, et al. (Eds.), Improving public health through mycotoxin control. IARC
Scientific Publication No. 158. Published by the International Agency for Research on Cancer (IARC), France.

5. Liew WPP, Redzwan SM (2018) Mycotoxin: Its impact on gut health and microbiota. Front Cell Infect Microbiol 8: 60 .

6. Omotayo OP, Omotayo AO, Mwanza M, Babalola OO (2019) Prevalence of mycotoxins and their consequences on human health. Toxicol Res 35(1): 1-7.

7. Bennett JW, Klich (2003) Mycotoxins. Clin Microbiol Rev 16(3): 497-516.

8. Channaiah LH, Maier DE (2014) Best management practices for the prevention of mycotoxin contamination. In: Leslie JF, Logrieco A (Eds.), Mycotoxin reduction in grain chains, John Wiley \& Sons Inc., New York, USA, pp. 78-89.

9. Bhat R, Rai RV, Karim A (2010) Mycotoxins in food and feed: present status and future concerns. Comprehensive Reviews in Food Science and Food Safety 9: 57-81.

10. Sorenson WG (1999) Fungal spores: hazardous to health? Environ Health Perspect 107(3): 469-472.

11. Mayer S, Curtui V, Usleber E, Gareis M (2007) Airborne mycotoxins in dust from grain elevators. Mycotoxin Res 23(2): 94-100.

12. Ferrao J, Bell V, Chabite IT, Fernandes TH (2017) Mycotoxins, food and health. Journal of Nutritional Health \& Food Science 5(7): 1-10.

13. Milicevic DR, Skrinjar M, Baltic T (2010) Real and perceived risks for mycotoxin contamination in foods and feeds: Challenges for food safety control. Toxins (Basel) 2(4): 572-592.

14. Wild CP, Gang YY (2010) Mycotoxins and human disease: a largely ignored global health issue. Carcinogenesis 31(1): 71-82.

15. Schertz H, Dänicke S, Frahm J, Schatzmayr D, Dohnal I, et al. (2018) Biomarker evaluation and toxic effects of an acute oral and systemic fumonisin exposure of pigs with a special focus on dietary fumonisin esterase supplementation. Toxins (Basel) 10(7): 296. 
16. FAO (2009) FAO's director-general on how to feed the world in 2050. Population and Development Review 35(4): 837-839.

17. Durate SCI, Pena A, Lino CM (2010) A review on ochratoxin A occurrence and effects of processing of cereal and cereal derived food products. Food Microbiol 27(2): 187-198.
18. https://monographs.iarc.fr/agents-classified-by-the-iarc/

19. Ostry V, Malir F, Toman J, Grosse Y (2017) Mycotoxins as human carcinogens-the IARC Monographs classification. Mycotoxin Res 33(1): 65-73. 